\title{
低放射化核融合材料の開発
}

\section{一一特にAl 合金について一}

\author{
鎌田耕治 \\ (名古屋大学プラズマ研究所) \\ （ 1985 年 8 月 29 日受理）
}

\section{Development of Low Activation Al Alloys for Fusion}

\author{
Kohji Kamada
}

(Received August 29, 1985)

\begin{abstract}
Development and characterization on low activation Al alloys for fusion are described. Selection of the alloys from the points of low induced activity, high electrical resistivity, high mechanical strength, and high ductility, undertaken on laboratory scale experiment, and subsequent industrial fabrication of a large plate with $1^{\mathrm{m}} \times 2^{\mathrm{m}} \times 25^{\mathrm{mm}}$ with its characterization are detailed. The alloy finally selected is $\mathrm{Al}-\mathrm{Mg} \mathrm{Li}$ alloy.
\end{abstract} The metallurgical reason of high electrical resistivity of this alloy is mentioned.

Further improvement of the alloy by powder metallurgy is also mentioned.

I 序

核融合は, 将来のエネルギー源と考光た場合核分裂と異なりその核的反応過程で放射能生成物を作らない 事が最大の利点と考えられている。即ち clean energyである。しかし核融合反応に伴う大量の中性子が装置 構成材料を放射化しては, 残念ながらての最大の利点も無意味に帰する恐れがある。例えばステンレス鋼を 真空容器などの構造材料とした場合，その放射能の量は分裂炉でのそれとあまり変らない。勿論装置の低誘 導放射化は装置の保守, 実験の難易度, 使用後の処理等々の問題を大きく軽減するが, それ以上に clean energy としての根本にかかわる事柄である ${ }^{1-3)}$ 。

核融合装置の低誘導放射化に関する材料の評価は 1973 年頃から既に米国において試みられ, V 合金 ${ }^{4)}$, $\mathrm{Ti}$ 合金 ${ }^{4,5)}, \mathrm{A} \ell$ 合金 $^{4,6,7)}, \mathrm{SiC}^{4,8,9)}$ ，グラファイド ${ }^{8,9)}$ などが主な評価対象とされていた。また $\mathrm{A} \ell$ 
合金に関しては低放射化と裔食の問題を主な対象として $\mathrm{A} \ell-\mathrm{V}-\mathrm{Si}$ 系, SAP ( Sintered Aluminum Alloy) $\mathrm{Al}-\mathrm{Mg}-\mathrm{Si}$ 系等の核融合用新合金の開発も行われてきた ${ }^{10-13)}$ 。一方 INTOR, STARF IREではステンレ ス鋼による標準的な設計の他に $\mathrm{A} \ell$ 合金を主とした真空容器, ブランケットの低放射化設計も行われている。 さらに本格的な設計研究としては名大プラズマ研究所の $\mathrm{R}$ 計画がある ${ }^{18,19)}$ 。

てれらの設計研究の主構造材料である A 1 合金は,低強度のために一般的には核融合第 1 壁材料としては不 向きと見られる傾向がある。しかし上述の評価の結果では，ガス放出 ${ }^{20)}$ ，第 1 壁の温度分布に起因する熱 応力, ディスラプション時の蒸発量等に関してはステンレス鋼よりもはるかに優れた性質をもっている。 この様な点を考慮して INTORの設計に関連した次の様な指摘がなされた ${ }^{17)}$ 。すなわち,

（1）ステンレス鋼は $5 〜 10 \mathrm{MW} \cdot \mathrm{yr} / \mathrm{m}^{2}$ の積算壁負荷に対しては損耗が大きく，それに見合う厚さにす ると熱応力が疲労限界を越え現実的な設計が困難になる。

（2） $\mathrm{Al}$ 合金は核的性質，熱的性質に関してはステンレス鋼よりもはるかに優れているが，現有の合金で は $150{ }^{\circ} \mathrm{C}$ 以上における強度低下が著しい。それを補うものとして $\mathrm{SAP}$, 瀻細強化 $\mathrm{Al}$ 合金が有望で, $400^{\circ} \mathrm{C}$ 程度までの強度の維持が可能であろう。

（3）しかし Al 合金真空容器壁が厚過ぎるとトリチウム増殖率が低下する。

本稿では $\mathrm{R}$ 計画を対象として開発した $\mathrm{Al}-\mathrm{Mg}-\mathrm{Li}$ 系合金の性質および工業的製造性について述べささら にてれ迄の実験結果から得られた今後の改良の指針および課題について解説する。

\section{III. 核融合蓄置の誘導放射能}

$3000 \mathrm{MW}$ ( thermal) で 2 年間にわたる連続 運転を行い，その停止後に予想される核融合装置お よび核分裂炉（溶融金属高速增殖炉，LMF BR）の 放射能の減衰を図 1 亿示す ${ }^{3)}$ 。LMFBRの放射能は 核分裂生成物であるのに対し, 核融合装置の場合は 材料の放射化である点は注意を要する。HT-9 フエ ライト鋼と 316 ステンレス鋼は 100 年以上も放射 能が非常に高いレベルを維持する。それに対しグラ ファイト, $\mathrm{SiC}$ は短時間に $10^{-8}$ も減衰する。しか し不純物，特に Fe が残留放射能の原因になる。一 方 $\mathrm{Al}$ は両者の中間で, 約 3 週間程度で $10^{-6}$ 程度の 減衰を示している。その後は全く一定の放射能レべ ルを維持しているが，てれは ${ }^{27} \mathrm{Al}(n, 2 n)^{26} \mathrm{Al}$

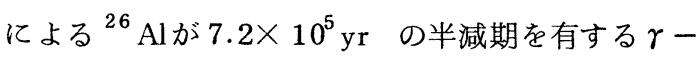

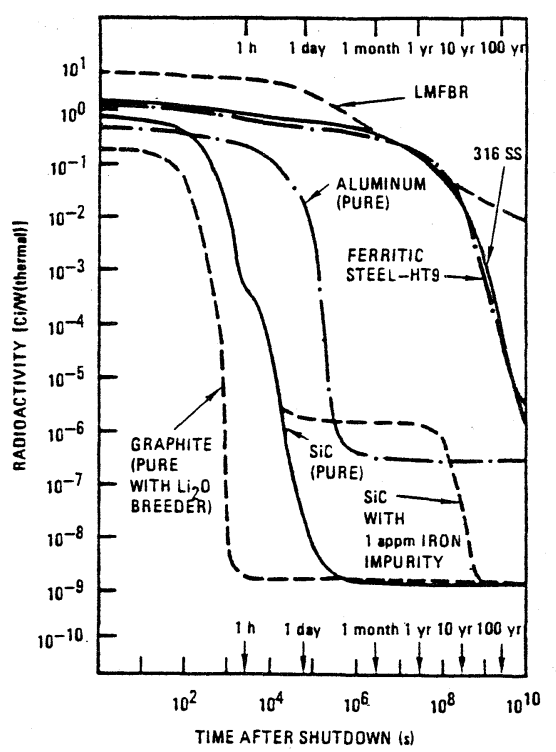

FISSION - LMFBR

FUSION - TOKAMAK FIRST.WALL AND BLANKET STRUCTURES FROM MATERIALS SHOWN (ALUMINUM, STEEL, SIC, AND GRAPHITE)

図 1. 種々の材料で作られた核融合妒および 核分裂炉の 2 年間, $3000 \mathrm{MW}$ (Hermal) 蓬転後の残留放射能。(3) 
emitterであるためとされている。しかしとてで注意を要するのは, ての様な評価に必要な核データ, 核変 換チェインの取り扱い, 装置の中性子スペクトルなどが必ずしも充分な精度で知られているとは限らないて とである。との計算は, $1.5 \mathrm{MW} / \mathrm{m}^{2}, 2$ 年間の $14 \mathrm{MeV}$ 中性子壁負荷による放射化として逆算すると, 約 $60 \mathrm{mb}$ 程度の反応断面積を使っているととが分かるが*1 , 最近の笹尾らの実験および理論計算 ${ }^{21)}$ の結果で は, ての反応のシキイ值は $14 \mathrm{MeV}$ 弱で, ての図の ${ }^{26} \mathrm{Al}$ とるレベルは大幅に減少すると考号れる。絶体 に ${ }^{26} \mathrm{Al}$ の生成を防止したければ,グラファイトなどによる中性子の低速化も考えられる1)。

次に放射能の減衰に伴う崩壊熱の問題がある。崩壊熱は図 1 の減衰率と放出エネルギーの積であるが, 表 $1^{(3)}$ に各種材料についての計算値を示す。この表は, $1.5 \mathrm{MW} / \mathrm{m}^{2}$ の壁負荷で 2 年間連続運転後の值であ る。“Adiabatic melting down time”は全く冷却のない状態における材料融解迄の時間で,てれはりえタ一 の様に強制的冷却の困難な場合に相当する。表の示す様に,グラファイト，SiC は全く冷却を必要としない。 “Post shutdown cooling cutoff time”は, 停止後のある時間から $\infty$ 時間の間で崩壊熱を積分し, その積 分值が材料の温度を融点迄上昇される程の熱量になるかどうかを計算して決められたものである。注意すべ きは，316ステンレス鋼が 30 年もの長期間冷却を要するととで，てれは放射能が高レベルを維持する問題 同様, 安全性, 解体, 排棄などの問題を非常に複雑にする。一方 $\mathrm{Al}$ 合金はりミターとして使用する場合は泠 却を必要とするが, 真空容器としては全く問題がない。

\section{表 1 . 運転停止後の崩壊熱に関する各種材料の挙動 \\ $\left(1.5 \mathrm{MW} / \mathrm{m}^{2}\right.$ の壁負荷で 2 年間罣転)。}

\begin{tabular}{lcccccc}
\hline & Graphite & SiC & $\begin{array}{c}\text { Aluminum } \\
\text { Alloy }\end{array}$ & $\begin{array}{c}316 \\
\text { Stainless } \\
\text { Steel }\end{array}$ & $\begin{array}{c}\text { Titanium } \\
\text { Alloy }\end{array}$ & $\begin{array}{c}\text { Vanadium } \\
\text { Alloy }\end{array}$ \\
\hline $\begin{array}{l}\text { Adiabatic } \\
\text { meltdown time }\end{array}$ & Infinite & Infinite & 17 min & 2 hours & 3 hours & 11 hours \\
$\begin{array}{l}\text { Post-shutdown } \\
\text { cooling cutoff time }\end{array}$ & Zero & Zero & 7 days & 30 years & 1 year & 1 day \\
$\begin{array}{l}\text { Afterheat at } \\
\text { shutdown }\left(\mathrm{W} / \mathrm{cm}^{3}\right)\end{array}$ & Nil & 0.9 & 1.1 & 0.6 & 0.4 & 0.2 \\
$\begin{array}{l}\text { Operating } \\
\text { temperature }(\mathrm{C})\end{array}$ & 1000 & 1000 & 150 & 400 & 400 & 400 \\
\hline
\end{tabular}

*1 金材技研 野田哲二氏の計算による。 


\section{III. $\quad R$ 計画の材料問題}

$\mathrm{R}$ 装置の 2 次設計では, 低誘導放射化のため真空容器, コイルケース, 外側ポロイダルコイル導体の 3 箇 所に $\mathrm{Al}$ 合金が採用された。この中で最も条件の厳しい真空容器材料としては，大きな電磁力に耐え得る強 度, 大型装置製作の加工性, 溶接性等のほかに, トカマクの 1 周抵抗を高くとり真空容器への電磁的パワー の投入を少なくし，同時にプラズマのディスラプション時およびトロイダル磁場の時間的変化により発生す る渦電流を最小限に抑えるために，その電気抵抗をできるだけ高くするという要請である。また 1 周抵抗を 上げるためにはベロー構造と絶縁ブレーク構造の 2 つが考えられるが, 前者をとるならば材料の延性もかな り必要になる。

てれらの事柄に関して必ずしも明確に決められた数值があるわけではないが, 強度や電気抵抗が高ければ それだけ設計上の余裕が得られるととになる。また真空容器であるからべーキングも必要になる。てのよう な事情から 2 次設計での材料選定として次のような配虑がなされた。

（1）大板（ $3 \mathrm{~m} \times 6 \mathrm{~m} \times 50 \mathrm{~mm} ）$ が製作可能なとと

（2）曲げ加工が容易なとと

（3）比較的高強度であるとと

（4） $120 \sim 140^{\circ} \mathrm{C}, 10^{4} \mathrm{~h}$ の加熱に対して, 時効による強度低下のないとと

（5）耐応力窝食割れ性を確保すること

（6）放電後 2 週間で放射能レベル $10^{-2} \mathrm{mrem} / \mathrm{h}$ 以下であるとと

(7) 高電気抵抗であるとと

（8）溶接性良好であるとと

なお， $\mathrm{R}$ 装置では 1 回の D一T放電当りの中性子フルエンスは, 真空容器表面で $210^{13} n / \mathrm{cm}^{2}$ であり, 全 $\mathrm{D}$ 一T 放電数を $2 \times 10^{3}$ 回程度とすると装置寿命中の全中性子フルエンスは $10^{16} \sim 10^{17} n / \mathrm{cm}^{2}$ になる。ち なみに動力炉では年間 $10^{21} \sim 10^{22} n / \mathrm{cm}^{2}$ のフルエンスが想定されている。したがって,動力炉で問題とな る崩壊熱, 照射損傷等は問題にならないと考光られる。

てれらの条件で $\mathrm{Al}$ 合金にとって特に難しいのは高電気抵抗である。Al 合金は低電気抵抗であるてとが実 用上の 1 つの利点になっている材料であり, 後で述べるように治金学的にも理由のあるてとで, 逆に高電気 抵抗を得ようとする努力は今までになされたととがなかったと思われる。

以下では, Al 新合金の開発の状況を解説するが, $\mathrm{Al}$ トカマクの設計に関しては $\mathrm{R}$ 計画デザインチームに よる技術報告 ${ }^{(18)}$ を参照されたい。

\section{IV. 低誘導放射化 $\mathrm{Al}$ 合金の開発}

低誘導放射化の観点からは材料の選択の幅が非常に限られるが, 現段階で工業的に供給可能な大型構造物 材料としては $\mathrm{Al}$ 合金以外に考えられない。しかし現有の $\mathrm{Al}$ 合金には放射化され易い元素が種々の目的で混 
入されていて, 低放射化材料とは言い難く, 新合金の開発が必要になる。その際, 低放射化と同時に機械的 性質などは現有合金の特性を損わず，さらに電気抵抗の増加を目指さねばならない。

$\mathrm{R}$ 計画での合金開発では，まず最小限の改良で現有合金の低放射化を達成するてと，および高性能の新合 金を開発するととの二段構えで計画を遂行した ${ }^{22-26)}$ 。 前者としては A 5083 の $\mathrm{Mn}$ を Bi に置き換えた $\mathrm{Al}$ $-\mathrm{Mg}-\mathrm{Bi}$ 系合金, 後者としては, 種々の試行錯誤の末, 強度, 電気抵抗の双方を向上させる $\mathrm{Al}-\mathrm{Mg}-\mathrm{Li}$ 系合金を選定した。合金系の選定理由は後述するとして，ててではてれら合金系に関する実験と，さらに選 定された $\mathrm{Al}-\mathrm{Mg}-\mathrm{Li}$ 合金の大板の製作について記述する。

\section{1. 合金系の選択}

表 2 に本研究で用いた合金の主要成分を示す。 表 2. 5083 改良合金および新 Al-Mg-Li 系合金の化学組成 $\mathrm{Al}-4.5 \sim 7.0 \% \mathrm{Mg}-0.2 \% \mathrm{Bi}$ 合金は, 5000 系 合金から残留放射能の高いマンガンを除去し， ビスマスを添加して耐応力窗食割れ性を考慮し たものである。 $\mathrm{Al}-4.1 〜 4.8 \% \mathrm{Mg}-0.3 \sim 1.3$ \% Li合金および $\mathrm{Al}-0.7 \sim 3.5 \% \mathrm{Li}-0.8 \sim 3.9$ $\% \mathrm{Mg}$ 合金は，リチウムの添加により合金の電 気抵抗を高めたものである。なお各合金共に結 晶粒微細化のために微量添加元素として, ジル コニウムを $0.10 \%$ ，クロムを $0.10 \%$ ，チタン を $0.05 \%$ 含有している。各供試合金は 99.75 $\% \mathrm{Al}$ と $99.9 \% \mathrm{Li}$ の地金を用いて, アルゴンガ 又雾囲気中で造塊した。

各合金の鋳塊は，均質化熱処理（743～773K $\times 28.8 \sim 86.4 \mathrm{ks})$, 熱間圧延 $(673 \sim 753 \mathrm{~K})$

\begin{tabular}{c|c|c|c|c}
\hline \multirow{2}{*}{$\begin{array}{c}\text { Alloy } \\
\text { Number }\end{array}$} & \multirow{2}{*}{$\begin{array}{l}\text { Alloy } \\
\text { System }\end{array}$} & \multicolumn{3}{|c}{ Chemical Composition (mass \%) } \\
\cline { 3 - 5 } & & $\mathrm{Mg}$ & $\mathrm{Li}$ & $\mathrm{Bi}$ \\
\hline 1 & & 4.46 & - & 0.19 \\
2 & & 4.95 & - & 0.16 \\
3 & Al-Mg-Bi & 5.48 & - & 0.23 \\
4 & & 5.98 & - & 0.19 \\
5 & & 6.99 & - & 0.16 \\
\hline 6 & & 4.20 & 0.40 & - \\
7 & & 4.12 & 0.79 & - \\
8 & Al-Mg-Li & 3.93 & 1.34 & - \\
9 & 4.75 & 0.34 & - \\
10 & & 4.56 & 0.80 & - \\
11 & & 4.67 & 1.34 & - \\
\hline 12 & & - & 0.70 & - \\
13 & & - & 1.77 & - \\
14 & & 1.97 & 1.67 & - \\
15 & & 2.92 & 2.00 & - \\
16 & Al-Li-Mg & 3.89 & 1.85 & - \\
17 & & - & 3.20 & - \\
18 & & 0.84 & 2.87 & - \\
19 & & 1.88 & 2.92 & - \\
20 & & 2.82 & 3.02 & - \\
21 & & - & 3.45 & - \\
\hline
\end{tabular}
冷間圧延によって厚さ $2 \mathrm{~mm}$ の板材にした。そ の後, $\mathrm{Al}-\mathrm{Mg}-\mathrm{Bi}$ 合金では軟化処理 (O材, $633 \mathrm{~K} \times 3.6 \mathrm{ks}), \mathrm{Al}-\mathrm{Mg}-\mathrm{Li}$ 合金では軟化処理 $(643 \mathrm{~K} \times 7.2 \mathrm{ks})$ および溶体化・時効処理 $(743 \mathrm{~K} \times 3.6 \mathrm{ks} \rightarrow W . Q . \rightarrow 453 \mathrm{~K} \times 86.4 \mathrm{ks})$, またその他の合金では溶体化・時効処理 $(743 \mathrm{~K} \times 3.6 \mathrm{ks} \rightarrow W . \mathrm{Q} . \rightarrow 453 \mathrm{~K} \times 86.4 \mathrm{ks})$ を行った。各材料は引張武験, 電気伝導度測定, TEM観察等を行い検討した なおての実験では室温での引張強度, 伸びおよび電気抵抗を目安として合金選定を行ったが, 電気抵抗は シグマテスターによる電気伝導度の測定から決定した。

図 2 k $\mathrm{Al}-\mathrm{Mg}-\mathrm{Bi}$ 系合金焼鈍材の強度, 伸び, 電気伝導度 ${ }^{* 2}$ を $\mathrm{Mg}$ 含有量の関数として示してある。

*2\% IACS は純銅の伝導度を $100 \%$ したときの相対值。電気抵抗への換算は次式で行う。

$$
\mu \Omega \mathrm{cm}=172.4 / \% \mathrm{IACS}
$$


$\mathrm{Mg}$ 含有量によるあまり大きな変化は見られ ないが, 電気伝導度は従来の合金よりも減少 していて望ましい方向である。しかし $\mathrm{Mg}$ を $5 \%$ 以上含むと熱間加工性が劣化し, 材料製 造の過程で問題となる ${ }^{(27)}$ 。

次に, $\mathrm{Al}$ 合金は $\mathrm{Li}$ の添加によりその性質 を非常に大きく変化させる。罒 3,4 亿その 様子を示す。前者は $\mathrm{Al}-\mathrm{Mg}-\mathrm{Li}$ 合金, 後者 は $\mathrm{Al}-\mathrm{Li}$ 二元合金での $\mathrm{Li}$ 含有量依存性であ る。図 3 亿示すのは焼鈍材の結果であるが， この実験範囲内では溶体化・時効材もはとん

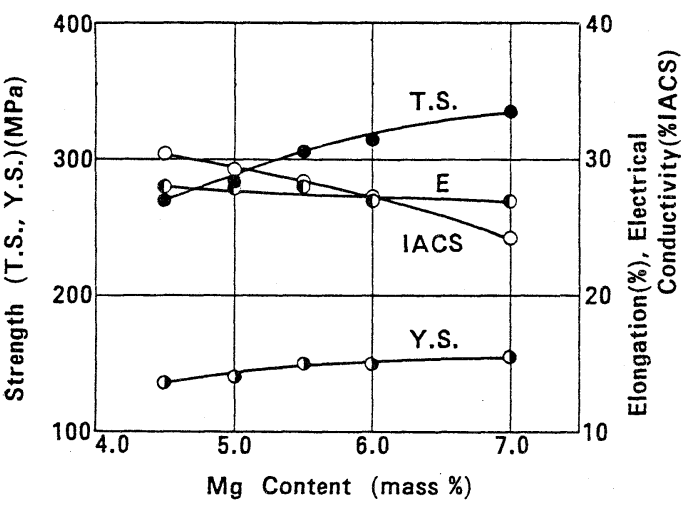

図 2.Al-Mg-Bi 合金における引張強度 (T.S.), 0.2\% 耐力 (Y.S.) , 伸び (E) および電気伝導度と $M g$ 含有量の関係。633K, $3.6 \mathrm{KS}$ 焼鈍後の值。 ど変わらなかった。てれらの図から分かる様 に, 引張強度, 耐力 $(0.2 \%)$ 共に Li 量に対してほぼ直線的に増加している。電気伝導度も著しく減少し, 特に急冷された場合はその効果が著しい。5083 合金焼鈍材の電気伝導度は約 $29 \%$ IACSであるから，例 えば $\mathrm{Al}-4.1 \% \mathrm{Mg}-1 \% \mathrm{Li}$ 焼鈍材の值 $20 \% \mathrm{IACS}$ は, 約 $30 \%$ の減少になる。伸びは Li 量と共に減少する が, $1 \% \mathrm{Li}$ 近傍では $20 \%$ 程度確保出来る。図 4 は $\mathrm{Al}-\mathrm{Li}$ 合金を $743 \mathrm{~K}, 3.6 \mathrm{ks}$ 溶体化処理後水中に急冷 し, さらに $453 \mathrm{~K}, 86.4 \mathrm{ks}$ の時効処理を行ったものである。ての結果から, Li 添加による強度の增加は約 $100 \mathrm{MPa} / 1 \% \mathrm{Li}$ である。また電気伝導度の減少も著しく, 特に急冷直後では $13 \% \operatorname{IACS}($ 約 $13 \mu \Omega \mathrm{cm})$ にも達する。との事は今後の合金開発にとって非常に参考になる事柄である。

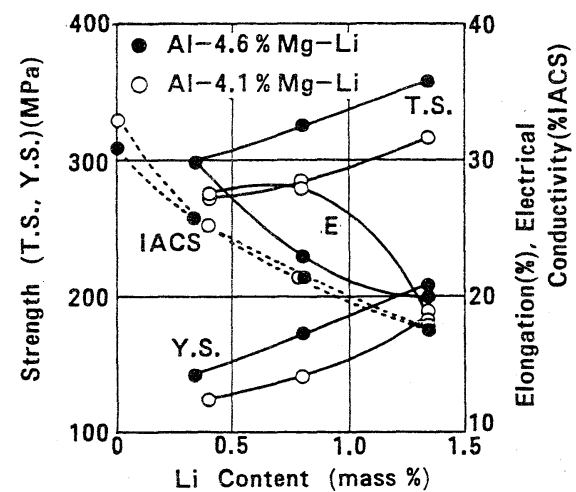

図 3. Al-Mg-Li 合金の引張強度 (T. S.), $0.2 \%$ 耐力 (Y.S.), 伸び (E), および䉓気伝導度 の Li 量依存性。643 K, $7.2 \mathrm{KS}$ 焼鈍後 の值。

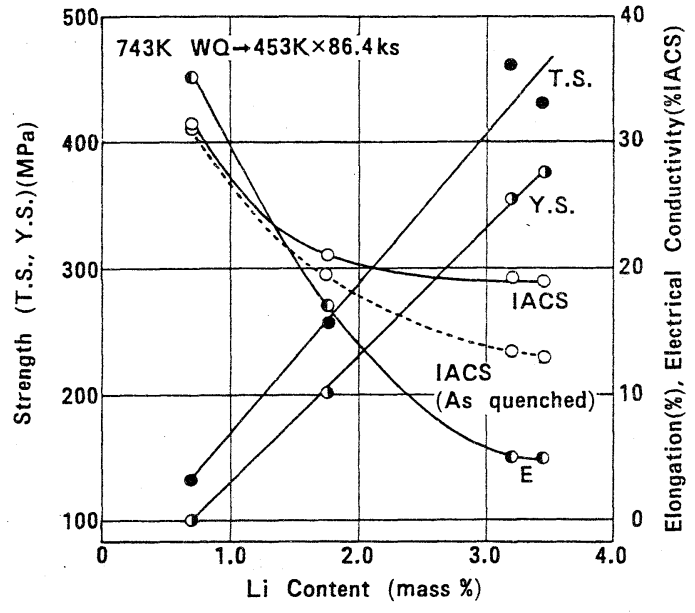

図 4，Al-Li 二元合金の強度，伸び，電気伝導度の Li 量 依存性。743 K, $3.6 \mathrm{KS}$ 㜔鈍後水中に急冷し, さらに $453 \mathrm{~K}, 86.4 \mathrm{KS}$ 焼鈍後の值。 
最後に $\mathrm{Al}-\mathrm{Li}-\mathrm{Mg}$ 系合金, すなわち at \%で Mg がLiより少ない合金で, $\mathrm{Mg}$ 含有量の影響を調べた結果 が, 図5，6である。熱処理条件は $\mathrm{Al}-\mathrm{Li}$ 系合金と同様である。この合金でも $\mathrm{Mg}$ の増加と共に強度が増加し電 気伝導度と伸びが減少している。特にLi 量が少ない程その効果は著しくなる。

また透過電子顕徵鏡観察の結果, $\mathrm{Li}$ 量 $1.5 \%$ 以上では $\mathrm{Al}_{3} \mathrm{Li}$ の折出による $\delta^{\prime}$ 相が観察され, $\mathrm{Li}$ 量が多 くなる程 $\delta^{\prime}$ 相の粒径が小さく, 分布密度が高くなる傾向がある ${ }^{26) 。 ~}$

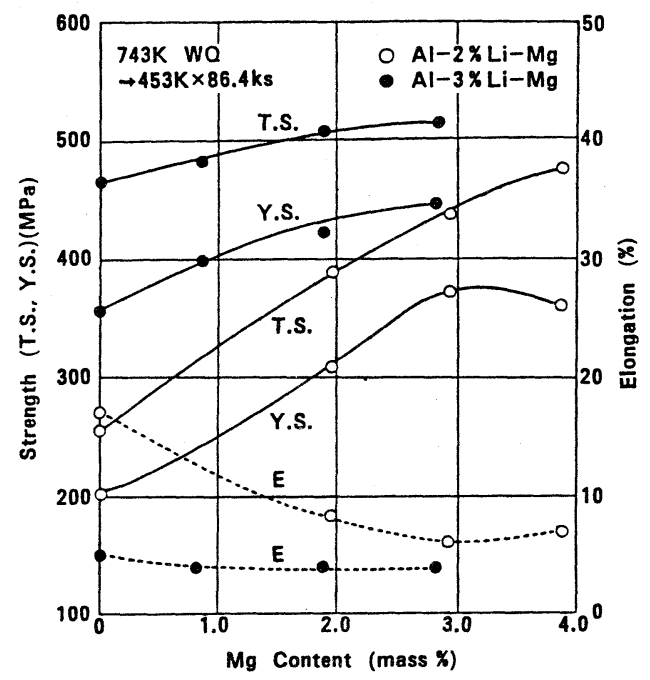

図 5.Al-Li-Mg 合金の強度, 伸びの Mg 量依存

性。熱処理条件は図 4 と同じ。

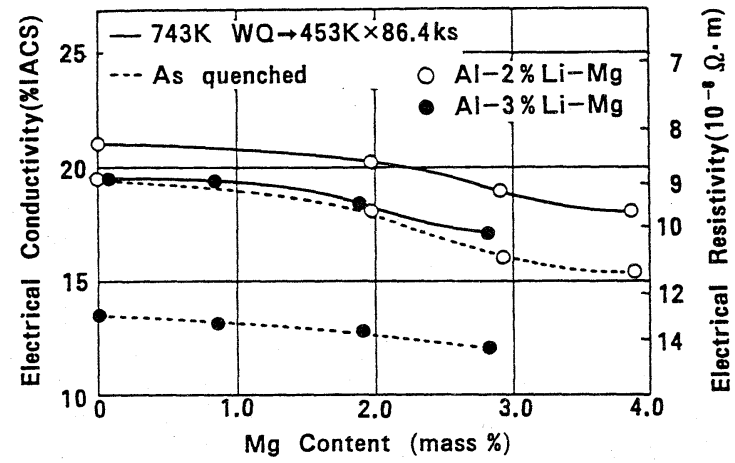

図 6.Al-Li-Mg 合金の電気伝㬝度。熱処理条件は図 4, 5 に同じ。 
図 7 に表 2 に示した各合金の引張強度と電 気伝導度を現有の合金と比較してある。

以上の様に今回開発した合金は現有の $\mathrm{Al}$ 合金に比べてかなりの改善になっている。特 にLi 量を多くすると強度, 電気抵抗に関し ては著しい。R計画では装置がベローズ構造 になるととを予想して，5083合金により図 8 の様な直径 $2 \mathrm{~m}$ の整形ベローズを試作し*3, そのために $20 \%$ 程度の伸びが必要になると とを確かめた。合金の選定にあたってはての 事を一つの目安とし, 引張強度 $300 \mathrm{MPa}$ 以上, 伸び $22 \%$, 電気抵抗 $8.6 \mu \Omega \mathrm{cm}$ を有する $\mathrm{Al}-$ 4〜 5\% Mg-1\% Li を最適合金として選定 した。

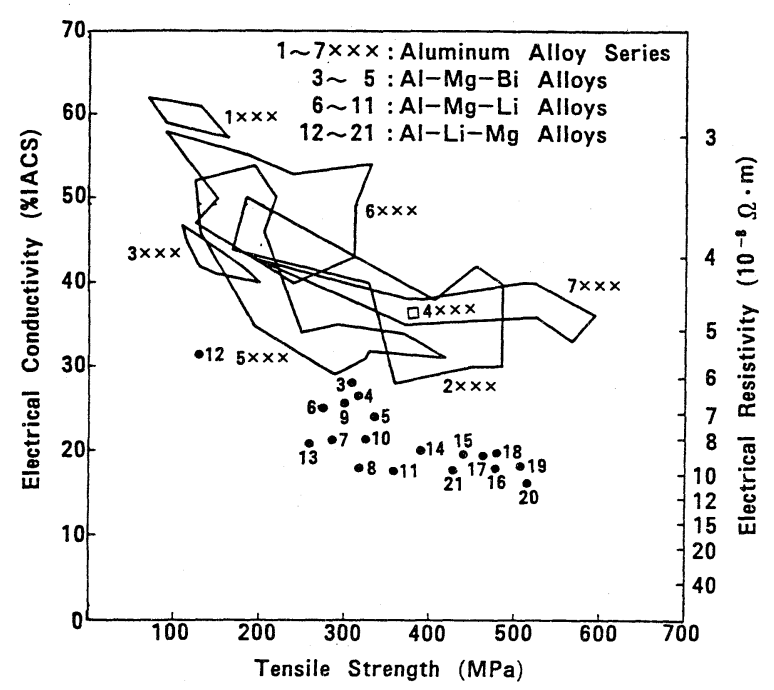

図7.表 2 に示した各合金の電気伝導度と引張強度の関係を 示す。現有の各種 AI 合金の值を比較のために示して ある。

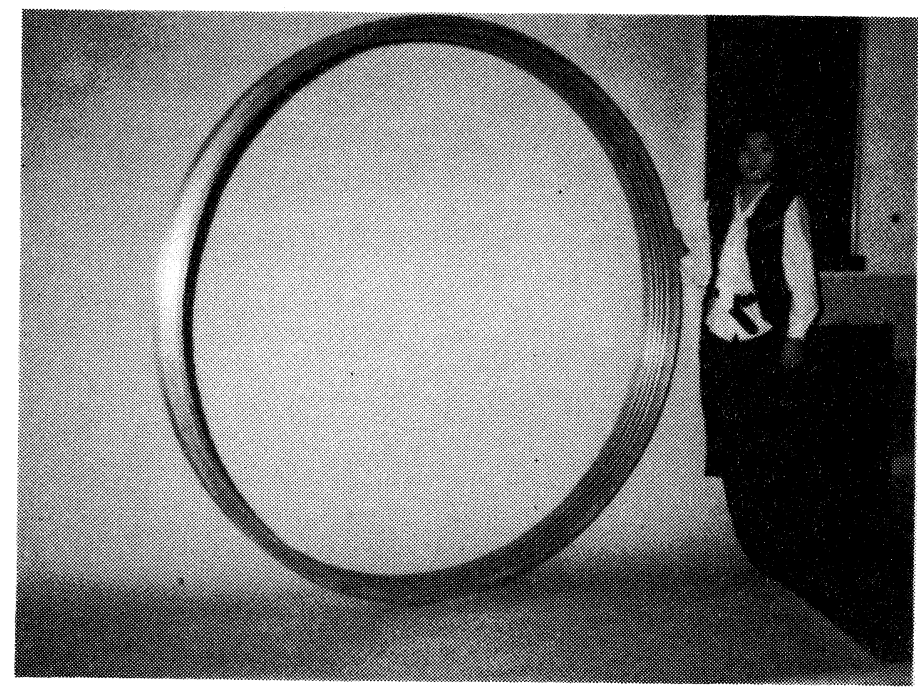

図 8.5083 合金で試作された直徍 $2 \mathrm{~m}$ の整形べローズ。 


\section{2. 大板の製造}

$\mathrm{R}$ 装置の設計では, トーラス方向に 8 分割し, さらにその 1 分割分を上下に分割してそれぞれを 1 枚の大板から 一体物で製作する案が出されている。ての場合の 1 枚の大板の大きさは $3 \mathrm{~m} \times 6 \mathrm{~m} \times 50 \mathrm{~mm}$ 程度になるてと が予想される。上述の新合金の中で 5083 改良型の場合は既に工業的基盤が確立していて，合金元素を部分 的に交換するだけで大板を作る上での技術的困難はないと思われる。しかし $\mathrm{Al}-\mathrm{Mg}-\mathrm{Li}$ 系合金の場合は， 現段階で工業的基盤は全くなく，多額の航空機材料として諸外国の $\mathrm{Al}$ メーカーが大規模な投資をしていると の情報はあるが，未だに大板の製造に成功したという情報はない。それだけに，溶解・鋳造から出発して大 板の製造までが工場規模で可能かどうか，さらに作った大板が上に述べたような性能を維持できるかどうか， 近い将来の核融合材料開発の一道程として確かめておく必要があった。

次下には工業的にも恐らく国内で初めてと思われるこの種合金の大板製造過程を, 将来の参考のために記 録に留めておく。

表 3 に目的とする大板の組成を示す。この中で $\mathrm{Zr}, \mathrm{Cr}$ は結晶粒微細化のため加え， Fe，Si は素材中の 不純物である。表 4 に製造工程の概要を示す。表の各工程について説明する。

\section{表 3. 試作合金大板の目標組成 （mass \%)}

\begin{tabular}{|c|c|c|c|c|c|c|}
\hline $\mathrm{Mg}$ & $\mathrm{Li}$ & $\mathrm{Zr}$ & $\mathrm{Cr}$ & $\mathrm{Fe}$ & $\mathrm{Si}$ & $\mathrm{Al}$ \\
\hline 4.0 & 1.0 & 0.15 & 0.08 & $\leqq 0.20$ & $\leqq 0.15$ & 残 \\
\hline
\end{tabular}

表 4.大板試作工程の概要

\begin{tabular}{|c|c|c|c|c|}
\hline 製 造 工 程 & 処 & 理 & 目 & 的 \\
\hline （1）溶 解 · 鋳 造 & \multicolumn{4}{|c|}{$\begin{array}{l}\text { 所定の化学成分を有するアルミニウム合金溶湯を溶解し, } \\
\text { 圧延用大型錆塊に錆造する。 }\end{array}$} \\
\hline $\begin{array}{l}\text { (2) 鋳塊の頭, 尾部 } \\
\text { 切断 }\end{array}$ & \multicolumn{4}{|c|}{ 鋳塊の頭部および尾部の非定常部を切断する。 } \\
\hline （3）均 質 化 処 理 & \multicolumn{4}{|c|}{$\begin{array}{l}\text { 鋳塊を高温で長時間加熱し，共晶化合物の溶入化をはかる } \\
\text { と共に熱間加工性を向上させる。 }\end{array}$} \\
\hline （4）鋳塊の表面切削 & \multicolumn{4}{|c|}{$\begin{array}{l}\text { 鋳塊表層部には偏析層や欠宿が存在するため, 圧延に先立 } \\
\text { って鋳塊表面を切削する。 }\end{array}$} \\
\hline （5）熱 間 压 延 & \multicolumn{4}{|c|}{ 鋳塊を熱間圧延により所定の形状の厚板に圧延する。 } \\
\hline (6) 乾 & \multicolumn{4}{|c|}{ 圧延後の厚板を焼鈍する。 } \\
\hline (7) 切断 · 仕上 & \multicolumn{4}{|c|}{ 所定の形状に切断し，必要に応じて板面の仕上を行う。 } \\
\hline
\end{tabular}


(1) 溶解・鋳造

溶解は大型炉を使用し, 約 $3000 \mathrm{Kg}$ のチャージを行った。溶解の順序は, まず $\mathrm{Al}$ を溶解し, $\mathrm{Mg}, \mathrm{Zr}$, $\mathrm{Cr}$ 等を添加し成分を調整した後にLi を溶湯中に添加した。

$\mathrm{Li}$ は極めて活性な金属で, 水, $\mathrm{O}_{2}, \mathrm{CO}_{2}$ などと激しく反応する。との工程でも図 9 亿示す様な形態の力 ス (酸化物) が多量に発生した。X線分析の結果, $\mathrm{Al}_{2} \mathrm{O}_{3}, \mathrm{MgO}, \mathrm{Li}_{2} \mathrm{CO}_{3}, \mathrm{Li} \mathrm{AlO}_{3}$ などが検出された。 $\mathrm{Li}$ 添加して化学組成を調整した後, 溶湯温度を $700{ }^{\circ} \mathrm{C}$ 亿保ち, $\mathrm{Ar}$ 雾囲気中で連続鋳造を行い, $300 \mathrm{~mm}$ $\times 1000 \mathrm{~mm} \times 2400 \mathrm{~mm}$ の形状に鋳造した。鋳造割れを生ずるととなく大型鋳塊の製作が可能であった。し かしての合金は湯流れ性が悪く, しかも溶湯の酸化が起てり易く, 鋳造性は一般の $\mathrm{Al}$ 合金に比べて著しく悪い。 図 10 に鋳塊の外観を示すが, 一般材に比べ表面状態も悪く，鋳造の難しい合金である。表 5 に鋳造時にサン プリングした溶湯の化学成分を示したが, 目標組成にほぼ等しいととが確認出来る。

溶解・鋳造工程で約 $800 \mathrm{Kg}$ が図 9 の様な酸化物として失われ, 溶解炬中の残湯, 炉壁への付着により約 $256 \mathrm{Kg}$ の溶湯口スを生じた。鋳塊の重量は $1944 \mathrm{Kg}$ である。

以上の様に, $\mathrm{Al}-\mathrm{Mg}-\mathrm{Li}$ 系合金の造塊は可能であったが, 溶解時の酸化口スが大きく, 溶湯が酸化され 易く, 鋳造性の悪いととが問題である。部留りよく厚板を製造するには溶解, 鋳造を完全に雰团気制御して 行う必要がある。それには大型鋳塊の雲囲気溶解鋳造技術の確立が必要である。

（2）鋳塊の頭部, 尾部の切断

一般に鋳塊の端部の非定常部には鋳塊欠陥が存在するために圧延前に切断が必要である。一般の $\mathrm{Al}$ 合金 では200〜300 mm切断するが，ての合金では頭部および尾部のそれぞれから $400 \mathrm{~mm}$ 切断した。これによ り鋳塊は $300 \mathrm{~mm} \times 1000 \mathrm{~mm} \times 1600 \mathrm{~mm}$, 重量 $1296 \mathrm{Kg}$ となった。

(3) 均質化処理

端部切断後, 均質化と熱間加工性向上のため, 鋳塊を $500^{\circ} \mathrm{C}, 8 \mathrm{hr}$ 加熱した。

(4) 表面切削

表層部にある偏析層, 欠陥の除去のため, 圧延前に表面切削を行う。一般合金では $30 \mathrm{~mm}$ 程度の表面切削 が行われるが，ての合金では欠陥を完全に除去するために片面約 $50 \mathrm{~mm}$ の表面切削が必要であった。約 519 $\mathrm{Kg}$ が切粉となり, 重量 $777 \mathrm{Kg}, 200 \mathrm{~mm} \times 900 \mathrm{~mm} \times 1600 \mathrm{~mm}$ の鋳塊となる。

（5）熱間圧延

表面切削した鋳塊を $480^{\circ} \mathrm{C}$ 加熱して可逆式 4 段熱間圧延機により圧延を行った。 $200 \mathrm{~mm}$ 厚から $130 \mathrm{~mm}$ 厚迄圧延したときに圧延材の頭部と尾部に割れが生じた。この割れを除去するために, 頭部 $350 \mathrm{~mm}$, 尾部 $250 \mathrm{~mm}$ 切断し, さらに表面で $15 \mathrm{~mm}$ の切削を行った。その後再び $480^{\circ} \mathrm{C}$ 加熱して $25 \mathrm{~mm}$ 厚迄圧延した。 熱間圧延終了後の形状 $25 \mathrm{~mm} \times 1400 \mathrm{~mm} \times 2800 \mathrm{~mm}$, 重量約 $264 \mathrm{Kg}$ であった。図 11 にその外観を示 す。

(6) 軟化 


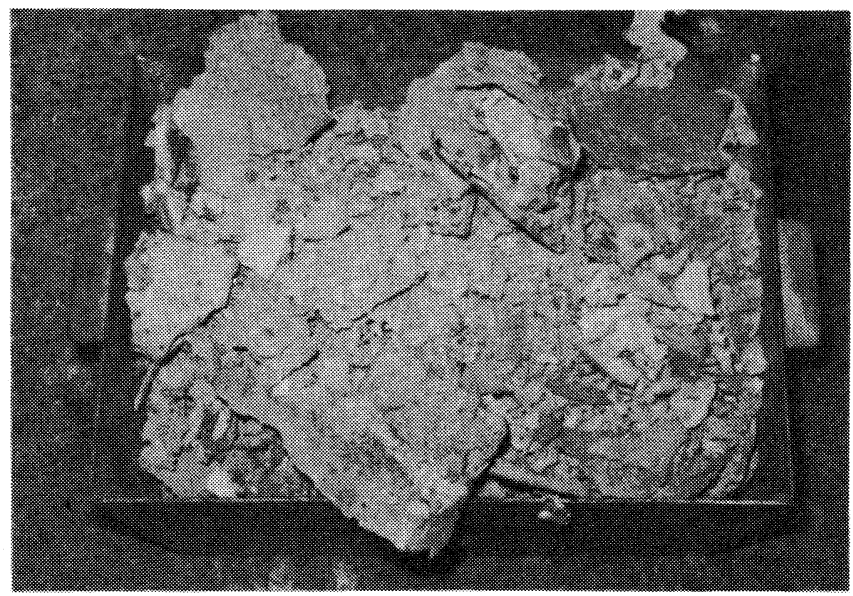

図 9．溶解工程で発生するカス（酸化物）。
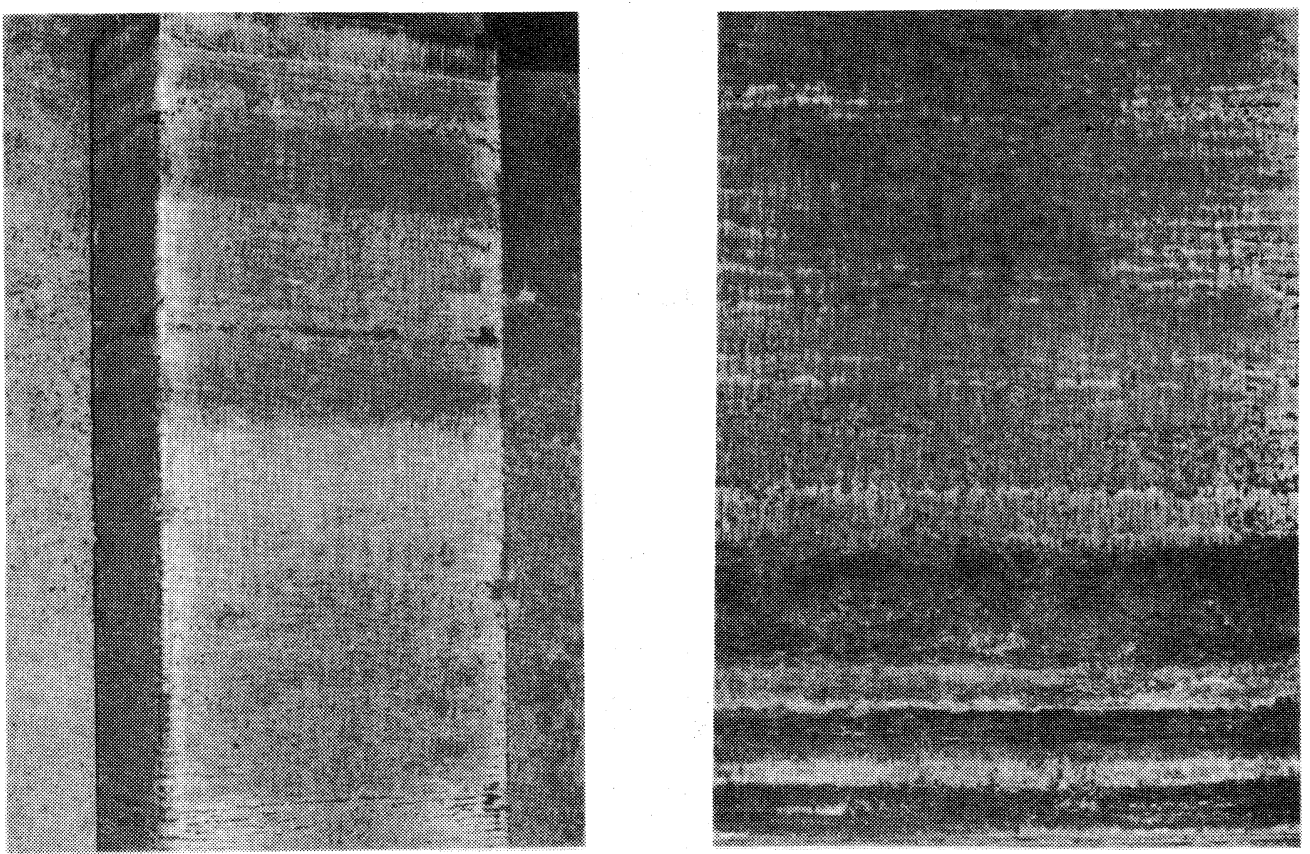

図10、鋳造されたインゴットの表面。

表 5. Al-Mg-Li 系合金の溶湯分析值 (mass \%)

\begin{tabular}{ccccccccccc}
\hline No. & $\mathrm{Mg}$ & $\mathrm{Li}$ & $\mathrm{Zr}$ & $\mathrm{Cr}$ & $\mathrm{Fe}$ & $\mathrm{Si}$ & $\mathrm{Mn}$ & $\mathrm{Cu}$ & $\mathrm{Zn}$ & $\mathrm{Al}$ \\
\hline 1 & 4.2 & 1.04 & 0.12 & 0.09 & 0.08 & 0.06 & $<0.01$ & 0.01 & $<0.01$ & bal. \\
\hline 2 & 4.2 & 1.01 & 0.14 & 0.09 & 0.08 & 0.05 & $<0.01$ & $<0.01$ & 0.01 & bal. \\
\hline 3 & 4.2 & 1.0 & 0.13 & 0.09 & 0.08 & 0.08 & $<0.01$ & 0.01 & $<0.01$ & bal. \\
\hline
\end{tabular}


熱間圧延終了後 $360^{\circ} \mathrm{C}, 1 \mathrm{hr}$ 焼鈍した。

(7) 切断, 仕上

最終的に $25 \mathrm{~mm} \times 1000 \mathrm{~mm} \times 2000 \mathrm{~mm}$ 重量 $135 \mathrm{Kg}$ の大板 1 枚が得られた。 表 6 に加工条件と材料歩留の概要を示す。

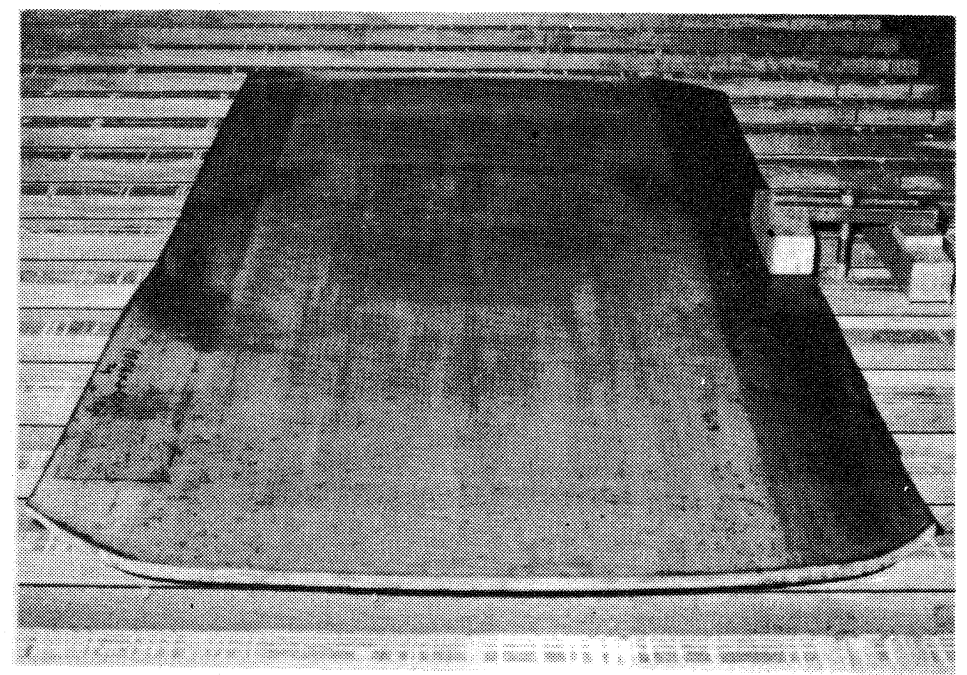

図11. 熱間圧延後の大板。

表 6.Al-Mg-Li 系大板の加工条件実績と材料部留

\begin{tabular}{|c|c|}
\hline I & 加工条件 . 材料歩留等 \\
\hline 溶 解 鋳 造 & $\begin{array}{l}\text { (1) 大型炬使用し } 3000 \mathrm{~kg} \text { の溶解実施。 } \\
\text { 溶解歩留的 } 73 \% \text { で約 } 800 \mathrm{~kg} \text { が酸化物として損失。 } \\
\text { (2) } \mathrm{Ar} \text { 需囲気中で } 300 \text { 厚 } \times 1000 \text { 幅 } \times 2400 \mathrm{~mm} \text { 長の鋳塊（重量 } 1944 \mathrm{~kg} \text { ）を造塊。 } \\
\text { 約 } 250 \mathrm{~kg} \text { の溶湯が残湯としてロスとなる。 }\end{array}$ \\
\hline $\begin{array}{l}\text { 鋳塊の頭部 · } \\
\text { 尾部切断 }\end{array}$ & $\begin{array}{l}\text { 鋳塊の頭部, 尾部を各々 } 400 \mathrm{~mm} \text { 切断し, } 300 \text { 厚 } \times 1000 \text { 幅 } \times 1600 \mathrm{~mm} \text { 長 }(1296 \mathrm{~kg}) \text { に } \\
\text { 加工。切断により約 } 650 \mathrm{~kg} \text { の切断屏が発生。 }\end{array}$ \\
\hline 均 質 化処理 & $500^{\circ} \mathrm{C}$ で $8 \mathrm{hr}$ 加熱。屏は発生せず。 \\
\hline 鋳塊の表面切削 & $\begin{array}{l}\text { 鋳塊表面を各々 } 50 \mathrm{~mm} \text { 切削して } 200 \text { 厚 } \times 900 \text { 幅 } \times 1600 \mathrm{~mm} \text { 長（777 kg）に加工。 } \\
\text { 切粉として } 519 \mathrm{~kg} \text { がロスとなる。 }\end{array}$ \\
\hline 熱 間 圧 延 & $\begin{array}{l}480^{\circ} \mathrm{C} \text { に加熱して } 25 \mathrm{~mm} \text { 板に圧延。压延時の面削等により約 } 513 \mathrm{~kg} \text { がロスとなる。 } \\
\text { 圧延後の形状は } 25 \text { 厚 } \times 1400 \text { 幅 } \times 2800 \mathrm{~mm} \text { 長で, 重量は約 } 264 \mathrm{~kg} \text { 。 }\end{array}$ \\
\hline 化 & $360^{\circ} \mathrm{C} \times 1 \mathrm{hr}$ 焼鈍。屑は発生せず。 \\
\hline 切断 . 仕上 & $\begin{array}{l}25 \text { 厚 } \times 1000 \text { 幅 } \times 2000 \mathrm{~mm} \text { 長に切断し, 表面仕上実施。完成品重量は約 } 135 \mathrm{~kg} \text { 。 } \\
\text { 切断時の残材を使用して性能試験実施。 }\end{array}$ \\
\hline
\end{tabular}




\section{3. 大板の性能}

圧延材から $1000 \mathrm{~mm} \times 2000 \mathrm{~mm}$ 大板を切り出し周返部残材は性能試験に使われた。図 12 亿各試験片の 採取部を示す。 $\mathrm{Al}$ から K5 迄の記号はての先の表にある記号に対応する。

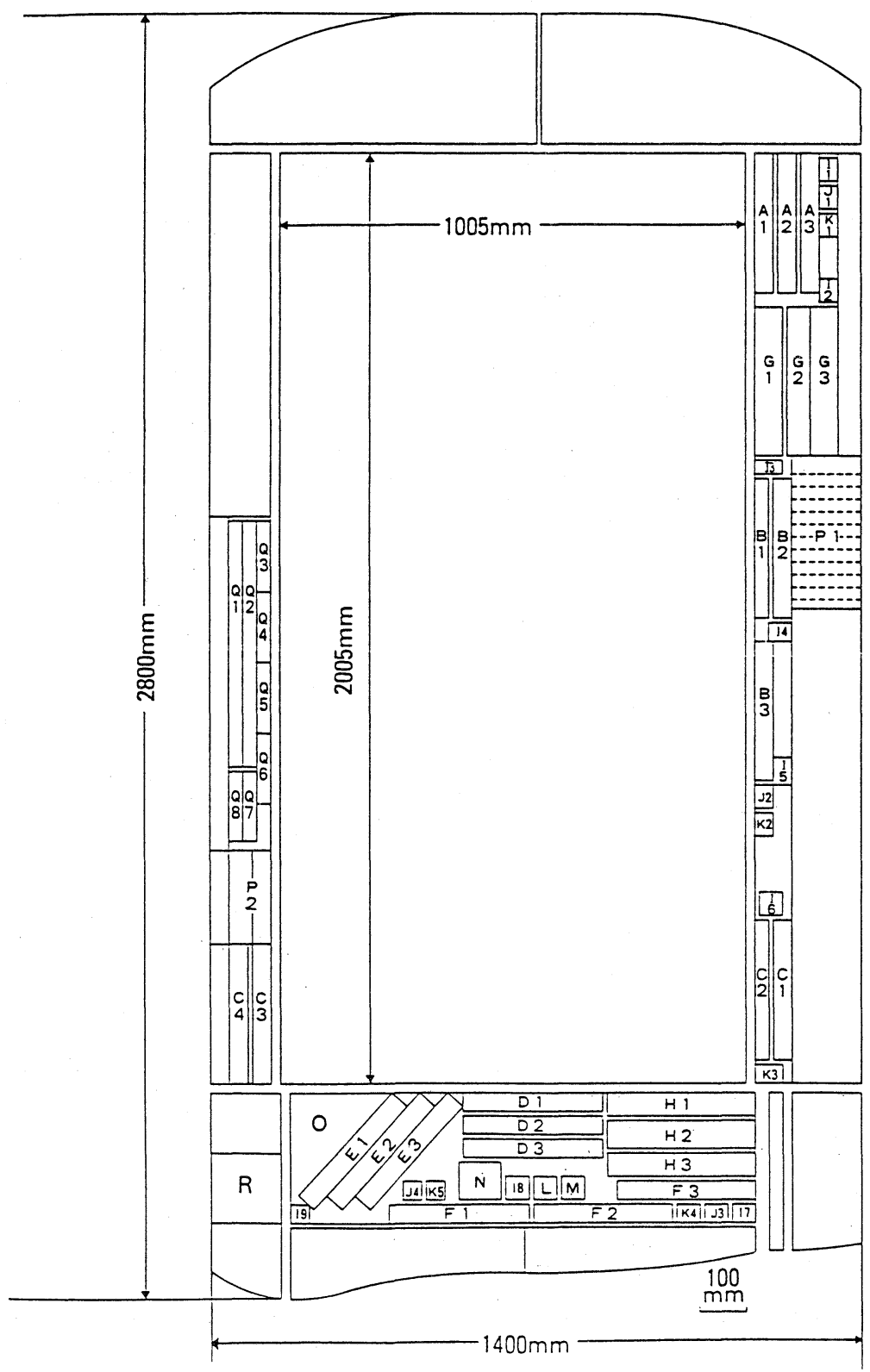

図12. 性能試験用に切り出された試料片の位置。A〜 K の各試料を実験に使用した。 
(1) 化学組成

表 7 亿圧延材の各部から取られた 4 つの試料について測定した組成を示す。先ず圧延材全体として非常に 均一に出来ているてとが明らかである。前述の様に $Z \mathrm{r}, \mathrm{Cr}$ は均質化過程での結晶粒微細化のために添加し たものであるが, 今後はVの様な比較的低放射化の元素で置換する必要がある。 $\mathrm{Fe}, \mathrm{Si}, \mathrm{Mn}, \mathrm{Cu}, \mathrm{Zn}$ は不純 物として混入したものであり, 今後高純度化の過程で問題になる。

表 7.大板材各部の化学組成 (mass \%)

\begin{tabular}{ccccccccccc}
\hline $\begin{array}{c}\text { Sample } \\
\text { notation }\end{array}$ & $\mathrm{Mg}$ & $\mathrm{Li}$ & $\mathrm{Zr}$ & $\mathrm{Cr}$ & $\mathrm{Fe}$ & $\mathrm{Si}$ & $\mathrm{Mn}$ & $\mathrm{Cu}$ & $\mathrm{Zn}$ & $\mathrm{Al}$ \\
\hline $\mathrm{J} 1$ & 4.1 & 1.02 & 0.12 & 0.09 & 0.09 & 0.07 & $<0.01$ & 0.01 & $<0.01$ & bal. \\
\hline $\mathrm{J} 2$ & 4.2 & 1.04 & 0.13 & 0.09 & 0.08 & 0.06 & $<0.01$ & $<0.01$ & $<0.01$ & bal. \\
\hline $\mathrm{J} 3$ & 4.2 & 0.95 & 0.11 & 0.09 & 0.08 & 0.07 & $<0.01$ & $<0.01$ & $<0.01$ & bal. \\
\hline $\mathrm{J} 4$ & 4.1 & 0.95 & 0.12 & 0.08 & 0.08 & 0.07 & $<0.01$ & 0.01 & $<0.01$ & bal. \\
\hline
\end{tabular}

（2）機械的性質

i）引張試験

荷重一伸び曲線の一例を図 13 亿示す。 $\mathrm{Al}-\mathrm{Li}$ 系合金の 特徵として激しい鋸歯状之りが見られる。15コの試料片に ついて $0.2 \%$ 耐力, 引張強度, 伸びを測定した結果を表 8 に示す。試料片形状は JIS 4 号試験片である。てれらの值 も非常に一様でばらつきの少ないととが明らかである。 C 3 の試料は耐力前に破断したが, 理由は不明である。と れらの值は $5083-\mathrm{O}$ 材 (耐力 $15 \mathrm{Kg} / \mathrm{mm}^{2}$, 引張強度 $29.5 \mathrm{Kg} / \mathrm{mm}^{2}$, 伸び $22 \%{ }^{28)}$ ）以上の性能を示している。 ii）曲げ試験

$12 \mathrm{~mm} \times 50 \mathrm{~mm} \times 300 \mathrm{~mm}$ の試験片を 2 種類, 長手方向 を圧延方向に平行 $(\mathrm{G} 1-\mathrm{G} 3)$ および直角 $(\mathrm{H} 1-\mathrm{H} 3)$ に 切り出し, 内側半径 $2 \times 12 \mathrm{~mm}$ で J IS 規格に準じて $180^{\circ}$ 曲げ試験を行った。その結果, 両方向とも割れを生じるて となく曲げが可能であった。したがって曲げ性も5083 合 金と同程度である。

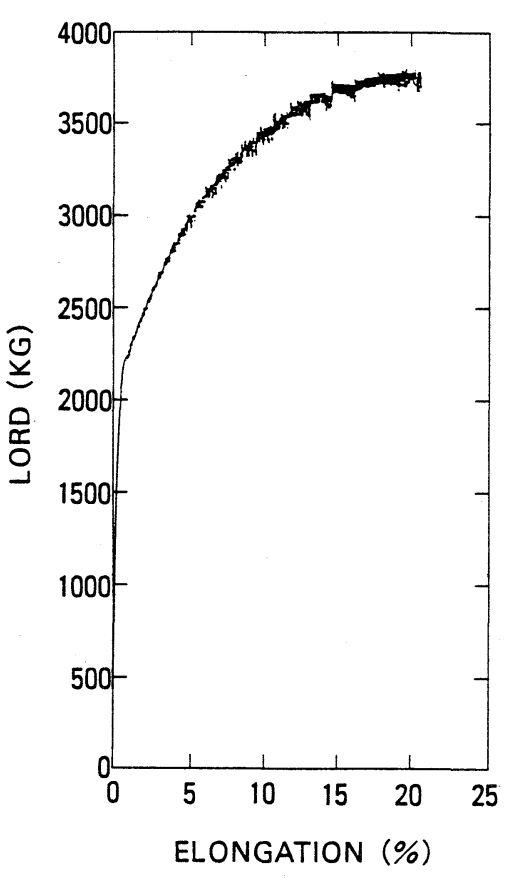

図13. 大板材の荷重・伸び曲線。 
iii）硬さ試験

$25 \mathrm{~mm} \times 50 \mathrm{~mm} \times 50 \mathrm{~mm}$ の試験片（Ｋ 1 - K 5 ）でVicker 硬さとRockwell 硬さを測定した。表 9 にそ の結果を示す。それぞれ 5 回の測定の平均である。硬さに場所による差は見られない。

表 8.大板材各部からとられた試料片の引張䧕度

\begin{tabular}{|c|c|c|c|c|c|}
\hline $\begin{array}{c}\text { Tensile } \\
\text { direction }\end{array}$ & Position & Notation & $\begin{array}{c}\text { Yield } \\
\text { stress } \\
\left(\mathrm{kg} / \mathrm{mm}^{2}\right)\end{array}$ & $\begin{array}{l}\text { Tensile } \\
\text { stress } \\
\left(\mathrm{kg} / \mathrm{mm}^{2}\right)\end{array}$ & $\begin{array}{c}\text { Elongation } \\
(\%)\end{array}$ \\
\hline \multirow{10}{*}{$\begin{array}{l}\text { Parallel } \\
\text { to } \\
\text { rolling } \\
\text { direction }\end{array}$} & \multirow{3}{*}{ Head } & A 1 & 18.8 & 32.8 & 22 \\
\hline & & A 2 & 18.5 & 32.6 & 25 \\
\hline & & A 3 & 18.8 & 32.9 & 22 \\
\hline & \multirow{3}{*}{ Middle } & B 1 & 18.5 & 32.5 & 24 \\
\hline & & B 2 & 18.9 & 32.7 & 21 \\
\hline & & B 3 & 19.0 & 32.5 & 20 \\
\hline & \multirow{4}{*}{ Tail } & $C 1$ & 18.7 & 32.0 & 22 \\
\hline & & $C_{2}$ & 18.3 & 31.2 & 23 \\
\hline & & $c 3^{*}$ & - & - & - \\
\hline & & C 4 & 18.8 & 31.3 & 23 \\
\hline \multirow{3}{*}{$\begin{array}{c}\text { Perpendicular } \\
\text { to } \\
\text { rolling } \\
\text { direction }\end{array}$} & \multirow{3}{*}{ Tail } & D 1 & 18.0 & 31.8 & 22 \\
\hline & & $\mathrm{D} 2$ & 17.8 & 32.0 & 24 \\
\hline & & D 3 & 18.3 & 32.0 & 23 \\
\hline \multirow{3}{*}{$\begin{array}{l}45^{\circ} \\
\text { to } \\
\text { rolling } \\
\text { direction }\end{array}$} & \multirow{3}{*}{ Tail } & E 1 & 17.7 & 31.9 & 24 \\
\hline & & E 2 & 18.0 & 32.3 & 20 \\
\hline & & E3 & 18.0 & 31.8 & 23 \\
\hline
\end{tabular}

奉 9、大板材各部からとられた式料片の硬度

\begin{tabular}{cccc}
\hline $\begin{array}{l}\text { Sampling } \\
\text { position }\end{array}$ & $\begin{array}{c}\text { Sample } \\
\text { notation }\end{array}$ & $\begin{array}{c}\text { Vickers } \\
\text { Hardness* } \\
(5 \mathrm{~kg})\end{array}$ & $\begin{array}{c}\text { Rockwell } \\
\text { Hardness* } \\
(\mathrm{F} \text { scale })\end{array}$ \\
\hline Head & $\mathrm{K} 1$ & 80.8 & 79.1 \\
\hline Middle & $\mathrm{K} 2$ & 81.7 & 79.3 \\
\hline Tail & $\mathrm{K} 3$ & 81.6 & 79.0 \\
\hline Tail & $\mathrm{K} 4$ & 80.2 & 78.8 \\
\hline Tail & $\mathrm{K} 5$ & 80.0 & 78.6 \\
\hline
\end{tabular}

iv）フラクトグラフィ

引張試験による破断面の走査電顕像を図 14 に示す。破断面は典型的な延性破壊を示す dimple 構造であ る。

V) 電気伝導度

表 10 に示す様に電気伝導度はほぼ均一で $21 \%$ IACS, 約 $8 \mu \Omega \mathrm{cm}$ 示している。

表10. 大板材各部の電気伝導度

\begin{tabular}{llllllllllll}
\hline $\begin{array}{l}\text { Sampling } \\
\text { Position }\end{array}$ & & Head & \multicolumn{1}{c}{ Middle } & & Tail \\
\hline $\begin{array}{l}\text { Sample } \\
\text { notation }\end{array}$ & 11 & 12 & 13 & 14 & 15 & 16 & 17 & 18 & 19 \\
\hline IACS (\%) & 20.8 & 20.9 & 20.9 & 20.5 & 20.8 & 20.5 & 21.2 & 21.2 & 21.2 \\
\hline
\end{tabular}



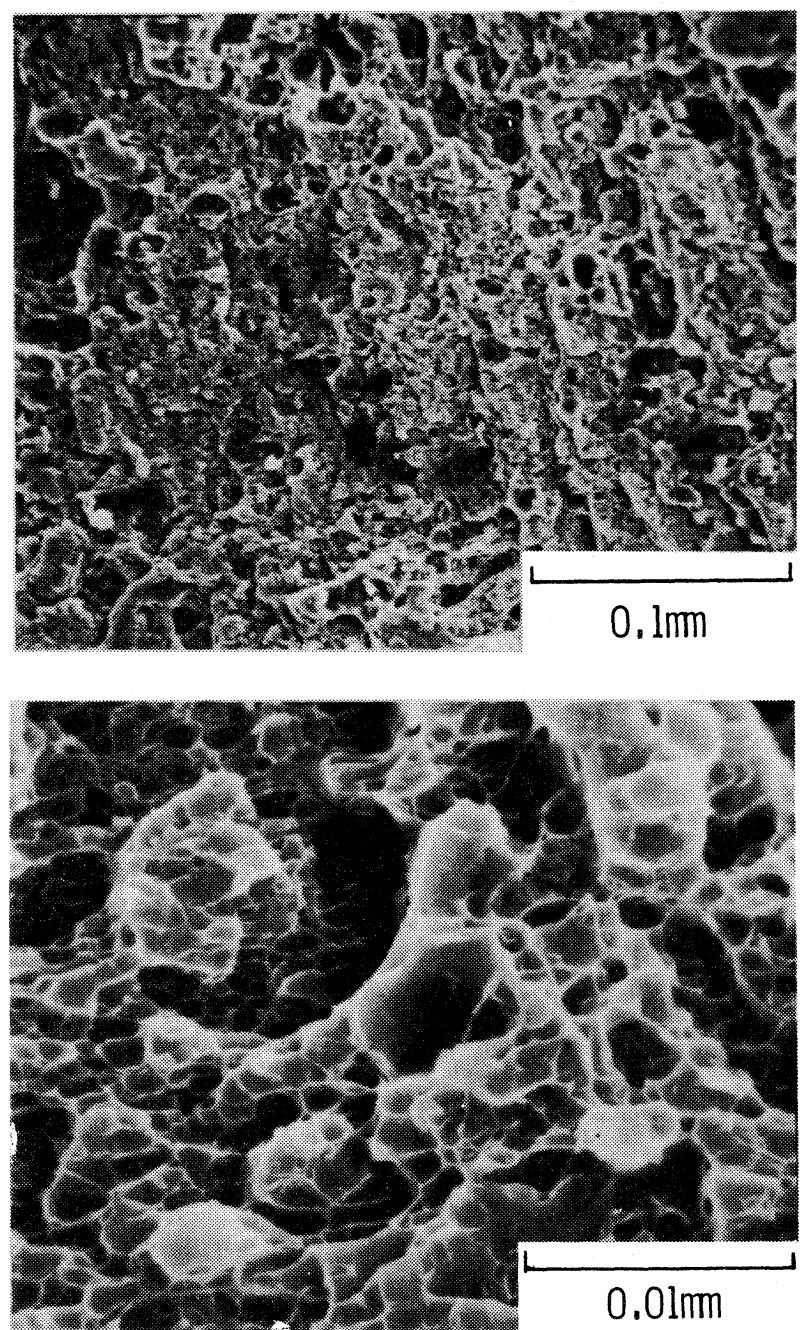

図14. 大板材試料片の引張破断面の SEM 像。

\section{4. 結 論}

以上の様に大板の性能は実験室規模で製作した小量溶解材の結果を再現している。てれにより, 材料の部 留を考えなければ大型装置のための材料供給は可能であり, その性能も現有の中強度 $\mathrm{Al}$ 合金 $5083-\mathrm{O}$ 材以 上を保証するととが可能である。 


\section{Al 合金の性質}

核融合材料として $\mathrm{Al}$ 合金を見た場合種々の得失のあるてとは勿論である。最大の利点は誘導放射能の減 衰が速いとと, 熱伝導度がよいとと, などであり, 最大の難点は低電気抵抗, 高温時効, 高温強度が低いて と等々であろう。特に低電気抵抗であったり時効型であったりする一つの原因は溶質元素の溶解度が低いて とである。表 117） に比較的溶解度の高い元素の一覧表を示す。幸にして Mg, Li は溶解度の最も高い部類に 属する元素である。それにしてもあまり大きな固溶限は持たず, 従って析出硬化には都合のよいものばかり である。

我々はての研究を始めるに際して, 電気抵抗に対する寄与の最も大きい合金元素を見出すために約 50 種 類程の様々な合金を作り，その結果としてLi を選択した。てのととは後になって表 11 に示す溶解度および 図 $15^{26)}$ 亿見られる各元素の電気抵抗值から納得出来た。図 15 は, 合金元素の原子価が $\mathrm{Al}$ の原子価から離 れるに従い電気抵抗が大きくなるととを示している。

表11. Al 中の元素固溶限 ${ }^{7)}$

\begin{tabular}{|c|c|c|c|c|c|}
\hline 温 度 & $2 \%$ 以上 & $1 \sim 2 \%$ & & 1 \% 以下 & \\
\hline 共晶温度 & $\begin{array}{l}\mathrm{Ag}(55.6), \mathrm{Cu}(5.65) \\
\mathrm{Ge}(2.8), \mathrm{Li}(4.0) \\
\operatorname{Mg}(14.8), \mathrm{Zn}(82.8)\end{array}$ & $\begin{array}{l}\mathrm{Mn}(1.82) \\
\mathrm{Si}(1.65) \\
\mathrm{Ti}(1.2) \\
\mathrm{W}(1.5)\end{array}$ & $\begin{array}{l}\mathrm{B}(<0.025) \\
\mathrm{Ca}(0.01) \\
\mathrm{Co}(<0.02) \\
\mathrm{Hf}(0.9) \\
\mathrm{Mo}(0.25) \\
\operatorname{Re}(0.26) \\
\mathrm{Sb}(<0.10) \\
\mathrm{V}(0.37)\end{array}$ & $\begin{array}{l}\mathrm{Ba}(<0.1) \\
\mathrm{Ce}(0.05) \\
\mathrm{Cr}(0.77) \\
\mathrm{In}(0.17) \\
\mathrm{Nb}(0.22) \\
\mathrm{Rh}(0.2) \\
\mathrm{Sn}(<0.01) \\
\mathrm{Y}(0.17)\end{array}$ & $\begin{array}{l}\mathrm{Be}(0.063) \\
\mathrm{Cd}(0.47) \\
\mathrm{Fe}(0.052) \\
\mathrm{La}(0.05) \\
\mathrm{Ni}(0.05) \\
\mathrm{Ru}(0.10) \\
\mathrm{Ta}(0.25) \\
\mathrm{Zr}(0.28)\end{array}$ \\
\hline 温 & $\operatorname{Mg}(2.9)$ & $\begin{array}{l}\mathrm{Ag}(1.03) \\
\mathrm{Li}(1.0) \\
\mathrm{Zn}(1.9)\end{array}$ & & & \\
\hline
\end{tabular}

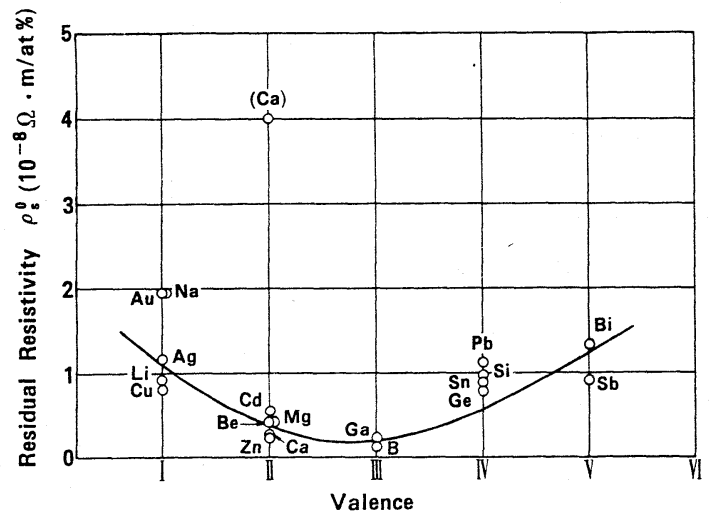

図15.A 合金中溶質原子の残留抵抗の原子価依存性。26) 
これまでに述べた $\mathrm{Al}-\mathrm{Mg}$-Li系および $\mathrm{Al}-\mathrm{Li}$

系合金の電気抵抗をLiの含有量に対してとって みると図 $16^{29)}$ の様になる。すなわち，Li量が $2 \%$ 程度までは $\mathrm{Mg}$ などの電気抵抗の影に隠 れているが，それ以上になるとほぼLi 量に 比例して電気抵抗が増加する。また焼鈍材よ りも急冷状態に近い方が電気抵抗への寄与が 大きい。乙の事は固溶状態の方が析出状態よ りも電気抵抗への寄与の大きいととを意味し ているがより電気抵抗の高い材料を開発す るために一つの示唆になる事実である。

次に $\mathrm{Al}$ の大きな利点である熱伝導度の高 い点であるが, 上述の大板材では室温で約 $1.6 \mathrm{~W} / \mathrm{cm} \cdot \operatorname{deg} ゙$ 現有の合金とほぼ同じ值を 保っている ${ }^{30)}$ 。またての合金での時効は, $500{ }^{\circ} \mathrm{C}$ 迄の比熱測定では $300^{\circ} \mathrm{C}$ 以上に析出 物の融解によると思われる小さな発熱が見ら れるが，それ以下では全く正常の比熱を示し ている。微小Vickers 硬さも $200^{\circ} \mathrm{C} 1$ 週間迄 の各温度での時効処理で何ら変化が見られな い31）。高温領域でも非常に安定した合金と 判断される。

$\mathrm{Al}$ 合金に対する偏見の一つに溶接の難 しさがある。しかしてれは全くの偏見であり， 現在 $\mathrm{Al}$ 合金の溶接はステンレス鋼同様全く問 題なく行われている。ただLiを含んだ合金の 場合は Li の反応性による種々の問題が予想 されるため, ·溶接性の試験を行った。その結 果を図 17 に示してある。ての眓は溶接部の 引張試験を行ったもので, 余盛があれば母材

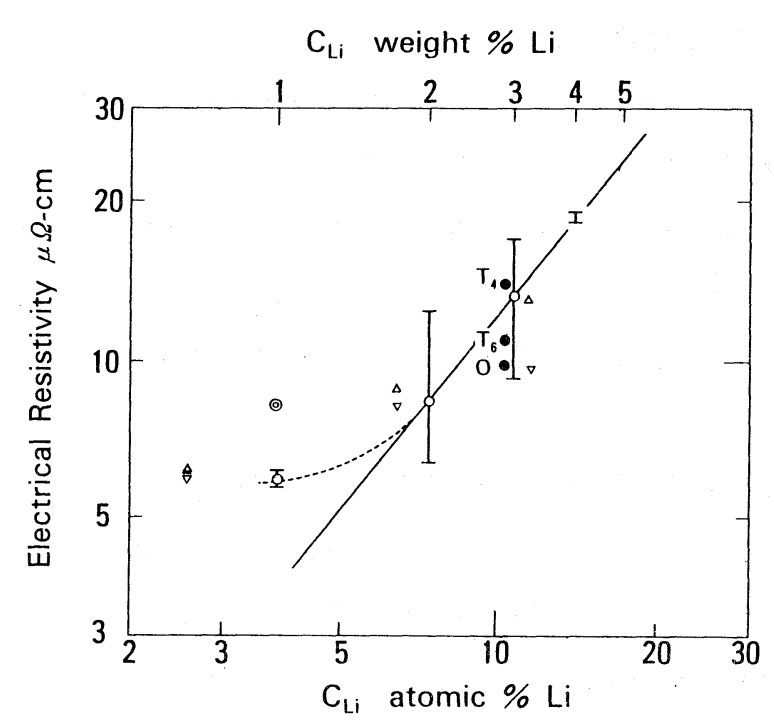

図16. Al-Mg-Li 合金の電気抵抗の $L i$ 量依存性。 29$)$ $0, T_{4}, T_{6}$ は調質を示す。

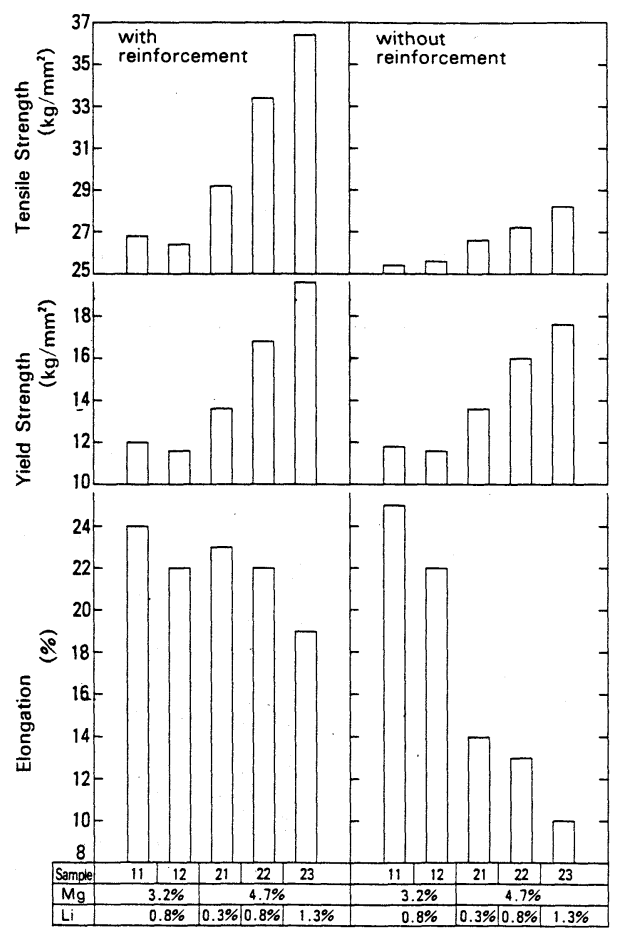

図17.Al-Mg-Li 合金の溶接性試験。 
よりも強度が増加している。伸びも母材と同 程度である。また溶接割れを生ずるとともな かったが, $\mathrm{Mg}$ 量が $4.7 \%$ の場合ブローホー ルを生ずるととがあった。

また我々は製造した大板材を使って直径 $300 \mathrm{~mm}$ 程度の超高真空チェインバーを製作

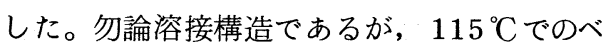
ーキングにより $7 \times 10^{-9}$ Torr の真空度が得 られている。またベーキング中も四重極質量 分析器でモニターを続けたが Li は全く観察さ れなかった。チェインバーの外観を図 18 に 示す。

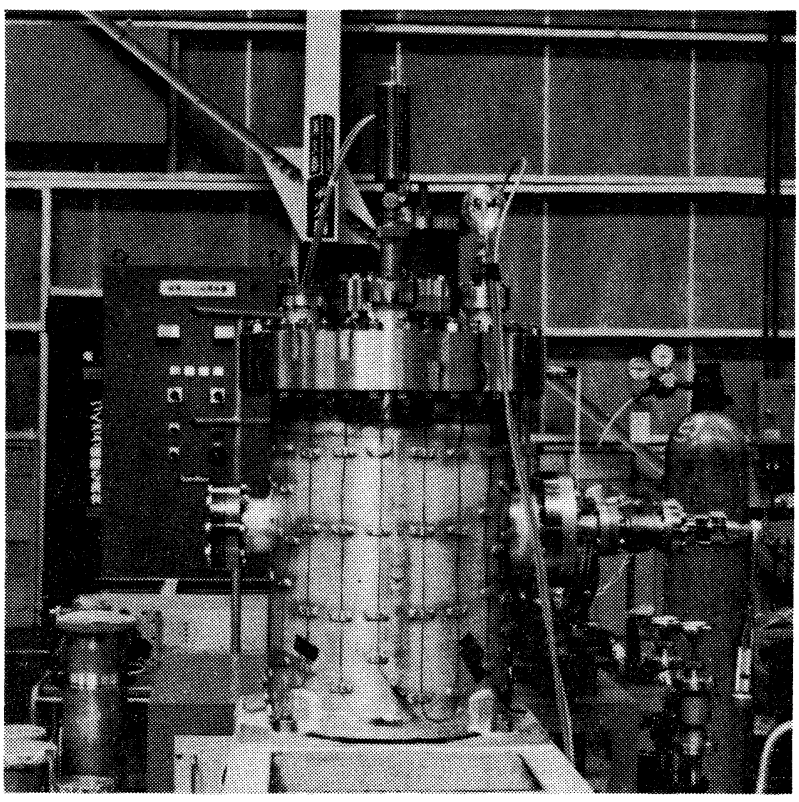

図18. Al-Mg-Li 大板材から製作した超高真空チェインバー。

\section{VI今後の課題}

核融合材料としての $\mathrm{Al}$ 合金の研究は全く緒 についたばかりのとてろで, 実用化迄持って 行くには様々な問題がある。特に重要と思わ れるのは照射損傷, その中でも $(\mathrm{n}, \mathrm{p})$ ， $(\mathrm{n}, \alpha)$ 反応による核変換損傷で, てれらに よる $\mathrm{H}, \mathrm{He}$ が粒界に蓄積して脆性破壊の原 因になるととは充分に考えられる。プラズマ 側表面からの水素同位体の注入もこれを加速 する。

また, 将来さらに材料強度, 電気抵抗など を向上させるために Li 含有量を増加させた 場合, 時効による高温強度の低下をどうする かも重要な問題である。

しかし, 現在すでに粉末治金材では非常に 高い強度のものが得られている。図 19 にそ の数例を示すが, 室温での強度ではステンレ ス鋼に匹適する值である。また我々が現在開 発中の $4 \% \mathrm{Li}$ を含有するある種の粉末治金材は,

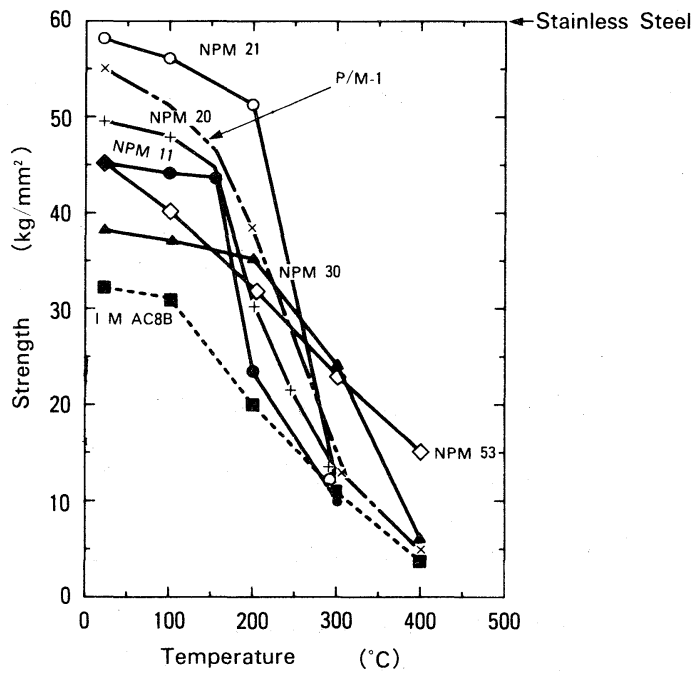
NPM $21 \quad$ Al-15\%Si-6\%Fe NPM $20 \quad$ Al-12\%Si-5\%Fe NPM $11 \quad$ Al-17\% Si NPM $30 \quad \mathrm{Al}-8 \% \mathrm{Fe}$ NPM 53 Al-3\%Carbon
$\mathrm{P} / \mathrm{M}-1 \quad$ Al- $4.4 \%$ Li- $1.1 \%$ Si- $1.0 \% \mathrm{M}_{\mathrm{n}}$

図19. 粉末治金 Al 合金の高温強度。 比较のために溶解材 $\mathrm{I} / \mathrm{M} \mathrm{AC8B}$ の值を挿入。 
室温で $55 \mathrm{Kg} / \mathrm{mm}^{2}(550 \mathrm{MPa}), 200^{\circ} \mathrm{C}$ も $38 \mathrm{Kg} / \mathrm{mm}^{2}(380 \mathrm{MPa})$ の強度があり, $170{ }^{\circ} \mathrm{C}$ 以上でも時効

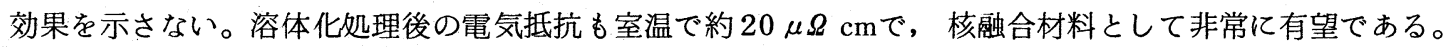
一方 $\mathrm{Al}$ を主体とした低放射化高強度材料としては, $\mathrm{SiC}$ 繊維強化複合材がある。ての種の材料は照射損傷 や熱衝撃に強くまた高温強度も高く, 今後発展の期待される材料である ${ }^{(32)}$ 。

\section{VII 結 び}

最近の ISP ( I gnition S tudy Prgram) に関する日米セミナーで, 次期装置として次の三つの選択が議論さ れたそうである ${ }^{33)}$ 。即ち门）非常に高度の装置の信頼性が得られれば, ステンレス鋼など既存の材料で装置を製 作し，実験終了後はそのまま放置するか，ii）低放射化材料で製作するか，またはiii）充分に広い空間を確保 して遠隔操作を可能にし既存の材料を使用する。著者が思うに门，，iii）の路線でステンレス鋼などを使用した 場合，装置の信頼性その他の条件が全て満たされたと仮定しても本稿の初めの部分で述べた様に長期間にわ たる装置の冷却や放置が必要になる。この様なシナリオは我国の様な立地条件の厳しい国では不可能ではな かろうか。核融合炉などになるとさらに事態は深刻である。

結論として, 核融合研究では低誘導放射化路線こそ最も現実的な方向であるとと, しかも装置の稼動温度 を比較的低く出来ればそれは $\mathrm{Al}$ 合金で可能であるととを強調したい。

なお本稿で述べた合金開発は名大プラズマ研究所と住友軽金属工業株式会社技術研究所の共同で行われた ものである。

\section{参考文献}

1) 垣花秀武, 日本原子力学会誌 24 (1982) 495 .

2) G. R. Hopkins and E. T. Cheng: Nucl. Tech./Fusion, 4 (1983) 528.

3) G. R. Hopkins, E. T. Cheng and H. E. Levine : GA-A 17389, October 1984.

4) "Conference Proceedings : Low Activation Materials Assessment for Fusion Reactors", EPRI ER-328-SR, March 1977, prepared by Mc Donnell Douglas Astronautics Company.

5) "Assessment of Titanium for Use in the 1 st Wall/Blanket Structure of Fusion Power Reactors", EPRI ER-386, April 1977, prepared by Mc Donnell Douglas Astronautics Company.

6) “Low-Activation Structural Materials for Fusion Reactors", Extreme Purity Base Aluminum Alloys. EPRI AP-2220, prepared by Alocoa Technical Center.

7）“核融合材料としてのアルミニウム合金” 核融合材料委員会報告書，昭和 59 年 5 月，軽金属協会。 
8) “Ceramic Materials for Fusion Reactors", EPRI AP-1702, February 1981, prepared by General Electric Company.

9) “Ceramic Materials for Fusion Reactors", EPRI AP-2515, July 1982, prepared by General Electric Company.

10) G. Piatti, F. Brossa, P. Fiorini and G. Giordano : J. Nucl. Mater, 103/104 (1981) 133.

11) P. Schiller : J. Nucl. Mater., 103/104 (1981) 75.

12) G. Piatti, P. Fiorini and P. Schiller : Nucl. Eng. Design. に印刷中。

13) P. Schiller, 私信。

14) J. R. Powell, F. T. Miles, A. Aronson and W. E. Winsche : BNL 18236, June 1973.

15) J. R. Powell, F. T. Miles, A. Aronson, W. E. Winsche and P. Bezler : BNL 18439, November 1973.

16) “Preliminary Reference Design of a Fusion Reactor Blunket Exhibiting Very Low Residual Radioactivity” ed. J. R. Powell, BNL 19565, December 1974.

17) J. R. Powell, J. A. Fillo, W-S. Yu et al:, in 4th Topical Meeting in Technology of Controlled Nuclear Fusion, 14-17, Oct. 1980.

18）核融合反応プラズマ実験装置技術報告 $I N-\mathbb{V I}, （$ 昭和57.6 - 59.12），名古屋大学プラズマ研究所 $\mathrm{R}$ 計画デザインチーム。

19）鎌田耕治，濱田泰司：日本原子力学会誌２4（1982）506.

20) 石丸 肇：日本原子力学会誌 26 (1984) 547 .

21）笹尾真実子：名大プラズマ研究所 Annual Review 1984.

22) K. Kamada, Y. Baba, T. Uno et al. : J. Nucl. Mater. 122/123 (1984) 845.

23）鎌田耕治，垣花秀武：日本原子力学会誌 27 （1985） 183 .

24) K. Kamada and H. Kayano : ICFRM-1, Tokyo, Dec. 1984.

25) K. Kamada : to be published in Nucl. Tech./Fusion.

26）正路美房，吉田英雄，宇野照生 他：軽金属 35（1985） 197.

27）堀内 良：軽金属 31（1981）431.

28）アルミウム・ハンドブック 昭和 53 年 5 月，軽金属協会。

29) K. Kamada and H. Kayano : unpublished data.

30) K. Kamada : unpublished data. 


\section{核融合研究 第54巻第 4 号 1985年10月}

31）里 達雄, 高橋恒夫 : 私信。

32) A. Kohyama, N. Igata, Y. Imai et al. : ICCM V, July 1985, San Diego.

33）松浦清剛： 私信。 